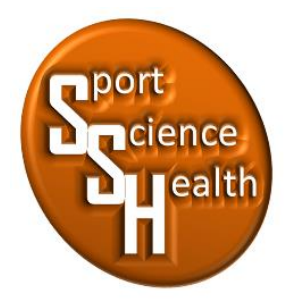

ISSN 2715-3886

\title{
Upaya Meningkatkan Pukulan Forehand Dropshot Bulutangkis Menggunakan Metode Variasi Untuk Atlet Usia 8-12 Tahun
}

\author{
Ahmad Zainul Arifin ${ }^{1 \star}$, Oni Bagus Januarto², Agus Tomi ${ }^{3}$ \\ 1,2,3 Jurusan Pendidikan Jasmani Kesehatan dan Rekreasi, Fakultas IImu Keolahragaan, \\ Universitas Negeri Malang, Jalan Semarang No. 5, Malang, Jawa Timur, 65145, Indonesia \\ ${ }^{*}$ Penulis koresponden: Ahmadzainularifin460@gmail.com, 083848525732
}

\begin{abstract}
The purpose of this study was to improve the forehand drops hot technique in athletes aged 8-12 years in PB Sari Agung, Banyuwangi using the variation exercise method. This research is a sports action research using qualitative descriptive and quantitative descriptive methods using 2 cycles and there are 4 stages: (1) planning, (2) implementation, (3) observation, and (4) reflection. The subjects in this study were 20 athletes aged 8-12 years. The results of the research that have been done show that the success rate of athletes aged 8-12 years in cycle 1 with the overall completeness of the forehand dropshot technique is $53.70 \%$ of observer 1 and $54.94 \%$ of observer 2 . While the success rate of age athletes $18-12$ years in cycle 2 with the overall com pleteness percentage of the forehand dropshot technique is $82.22 \%$ from observer 1 and $84.44 \%$ from observer 2 . Based on the results of the studyit can be concluded that using the variation exercise method can improve the forehand dropshot technique in athletes aged 8-12 years.
\end{abstract}

Keyword: the forehand dropshot technique; variation method

Abstrak: Tujuan penelitian ini adalah untukmeningkatkan teknik pukulan forehand dropshot pada atlet usia 812 tahun di PB Sari Agung Kabupaten Banyuwangi menggunakan metode variasi latihan. Penelitian ini merupakan penelitian tindakan olahraga dengan menggunakan metode deskriptif kualitatif dan deskriptif kuantitatif dengan menggunakan 2 siklus dan terdapat 4 tahapan yaitu: (1) perencanaan, (2) pelaksanaan, (3) pengamatan (observasi), dan (4) refleksi. Subjek dalam penelitian ini adalah 20 atlet usia $8-12$ tahun. Hasil dari penelitian yang sudah dilakukan menunjukkan bahwa tingkatkeberhasilan atlet usia 8-12 tahun pada siklus 1 dengan persentase ketuntasan keseluruhan teknik pukulan forehand dropshotsebanyak $53,70 \%$ dari observer 1 dan sebanyak 54,94\% dari observer 2 . Sedangkan tingkat keberhasilan atlet usia 18-12 tahun pada siklus 2 dengan persentase ketuntas an keseluruhan teknik pukulan forehand dropshotsebanyak $82,22 \%$ dari observer 1 dan sebanyak $84,44 \%$ dari observer 2 . Berdasarkan hasil penelitian dapat disimpulkan bahwa dengan menggunakan metode variasi latihan dapat meningkatkan teknik pukulan forehand dropshotpada atlet usia 812 Tahun.

Kata kunci: teknik pukulan forehand dropshot; metode variasi

\section{PENDAHULUAN}

Olahraga merupakan aktivitas yang digemari oleh masyarakat pada saat ini. Adi \& Fathoni (2020) menjekaskan bahwa olahraga adalah aktivitas fisik yang menggunakan otot-otot besar dalam melaksanakan 
aktivitas tersebut yang mempunyai ciri permainan dan kompetitif. Menurut Cohen, Texier, Quéré, \& Clanet (2015) bulutangkis adalah suatu olahraga yang menggunakan raket dimainkan oleh dua orang (untuk tunggal) atau dua pasangan (untuk ganda) yang mengambil posisi berawalan di bidang lapangan yang dibagi dua oleh sebuah jaring (net). Phomsoupha \& Laffaye (2015) mengemukakan bahwa bola bulutangkis tidak dipantulkan dan harus dimainkan di udara, sehingga permainan ini merupakan permainan cepat yang membutuhkan gerak refleks yang baik dan tingkat kebugaran yang tinggi. Berdasarkan pemaparan ahli dapat disimpulkan bahwa bulutangkis adalah permainan olahraga yang dilakukan 1 sampai 2 orang dipisahkan dengan jaring net alat yang digunakan yaitu raket dan shuttlecock sebagai bola serta cara gerakan memukul dengan refleks yang cepat dan lambat.

Antusias masyarakat terhadap olahraga bulutangkis sangat tinggi, banyak masyarakat yang memainkan olahraga bulutangkis untuk kegiatan prestasi maupun kegiatan rekreasi. Bulutangkis untuk kegiatan rekreasi biasanya dilakukan oleh orang muda, dewasa, hingga tua serta masyarakat biasanya melakukan olahraga bulutangkis untuk kesenangan dan melepas lelah. Permainan bulutangkis sendiri dapat dilakukan di tempat tertutup maupun ruangan terbuka. Anak-anak yang berlatih serius di cabang olahraga bulutangkis ini dapat meraih prestasi serta didorong dari pembinaan yang baik, berlatih yang tekun, disiplin, penguasaan teknik dasar juga berpengaruh untuk nantinya, sehingga nantinya banyak prestasi-prestasi yang ditorehkan dari tingkat Nasional maupun Internasional (Fattahudin, Januarto, \& Fitriady, 2020).

Banyak cara yang bisa dilakukan agar kegiatan olahraga yang dilakukan menjadi prestasi. Salah satunya dengan berlatih sungguh-sungguh, mengikuti pelatihan khusus dan mengikuti berbagai pertandingan yang diadakan sebagai upaya untuk mengasah kemampuan yang sudah didapatkan selama latihan (Adi \& Fathoni, 2019). Dari cabang olahraga yang berkembang di Indonesia, olahraga bulutangkis cukup digemari oleh masyarakat saat ini selain cabang olahraga sepakbola, bulutangkis tidak hanya digemari masyarakat, tetapi dari cabang olahraga bulutangkis ini banyak prestasi ditorehkan kancah dunia dan antusias masyarakat untuk olahraga ini cukup besar.

Ternyata olahraga bulutangkis pada masa sekarang ini bukan hanya sebagai olahraga rekreasi melainkan telah menjadi olahraga prestasi, maka tidak heran apabila dalam permainan bulutangkis para pemain dituntut prestasi setinggi-tingginya. Adanya tuntutan prestasi yang tinggi, maka perlu dilakukan latihan yang lebih efektif dan efisien, terutama dalam metode latihan, sehingga penguasaan teknik dasar dapat dikuasai dengan sempurna.

Penguasaan teknik dasar merupakan suatu yang perlu dikembangkan untuk prestasi permainan. Teknik dasar bulutangkis harus betul-betul dipelajari terlebih dahulu, guna mengembangkan mutu prestasi bulutangkis sebab menang atau kalahnya seorang pemain di dalam suatu pertandingan salah satunya ditentukan oleh penguasaan teknik dasar permainan. Dalam permainan bulutangkis, terdapat teknik dasar pukulan atas (overhead stroke) maupun pukulan bawah (underhand stroke).

Paramitha \& Anggara (2018) menjelaskan bahwa olahraga dibagi menjadi 5 sesuai fungsinya. (1) olahraga pendidikan yang bersifat mendidik, (2) olahraga rekreasi bersifat rekreatif, (3) olahraga kesehatan untuk pembinaan kesehatan, (4) olahraga rehabilitasi untuk rehabilitasi, (5) olahraga kompetitif untuk meningkatkan prestasi. Upaya meningkatkan prestasi dalam olahraga adalah tujuan utama dalam olahraga prestasi, termasuk dalam cabang olahraga bulutangkis. Dengan prestasi olahraga yang tinggi dapat mengharumkan nama bangsa dan negara.

Di Kabupaten Banyuwangi banyak ditemui tempat berlatih bulutangkis salah satunya, adalah PB. Sari Agung yang beralamatkan di JL. Curang Tangi Barat, Desa Setail, Kecamatan Genteng, Kabupaten Banyuwangi yang memiliki atlet beragam usia mulai dari usia 8 tahun hingga 20 tahun. Menurut Bapak Zainul Arifin selaku pelatih kepala terdapat total 56 atlet terdiri dari 37 atlet putra dan 19 atlet putri. Berdasarkan hasil observasi permainan pada atlet bulutangkis di PB. Sari Agung Genteng Kabupaten Banyuwangi dengan dibantu pelatih menghasilkan persentase yang di paparkan pada Tabel 1 . 
Tabel 1. Data Hasil Observasi Permainan Bulutangkis

\begin{tabular}{|c|c|c|c|c|}
\hline \multirow[t]{2}{*}{ No } & \multirow[t]{2}{*}{ Teknik } & \multirow[t]{2}{*}{ Total Intensitas } & Benar & Salah \\
\hline & & & $\%$ & $\%$ \\
\hline 1 & Service & 60 & $70 \%$ & $30 \%$ \\
\hline 2 & Forehand lob & 130 & $86 \%$ & $13 \%$ \\
\hline 3 & Smash & 19 & $57 \%$ & $42 \%$ \\
\hline 4 & Netiing & 57 & $70 \%$ & $29 \%$ \\
\hline 5 & Dropshoot & 65 & $33 \%$ & $66 \%$ \\
\hline 6 & Backhand lob & 51 & $58 \%$ & $41 \%$ \\
\hline
\end{tabular}

Hasil data tersebut didapat dari observasi awal yang dilakukan peneliti dengan dibantu pelatih saat sesi main single game 11 secara bergantian yang melibatkan atlet dari PB. Sari Agung Genteng Kabupaten Banyuwangi sebanyak 20 atlet. Data yang didapat dengan kriteria benar jika shuttlecock masuk ke lapangan lawan dan kriteria salah jika shuttlecock tidak tepat sasaran ataupun keluar lapangan (out) dan menyangkut di net. Hasil data yang tersaji adalah teknik servis sebanyak 60 kali dengan tingkat kebenaran $70 \%$ dan tingkat kesalahan $30 \%$, teknik forehand lob dengan jumlah pukulan 130 tingkat kebenaran $86 \%$ dan kesalahan $13 \%$, teknik smash dengan jumlah pukulan 19 tingkat kebenaran $57 \%$ dan kesalahan $42 \%$, teknik netting dengan jumlah pukulan 57 tingkat kebenaran $70 \%$ dan kesalahan 29\%, teknik dropshot dengan jumlah pukulan 65 tingkat kebenaran $33 \%$ dan kesalahan $66 \%$, teknik backhand lob dengan jumlah pukulan 51 tingkat kebenaran $58 \%$ dan kesalahan $41 \%$.

Dari hasil observasi yang dapat dilihat dari permainan atlet dapat diketahui bahwa teknik dasar pukulan dropshot bulutangkis sangatlah kurang dibandingkan teknik dasar lainnya. Untuk selanjutnya peneliti melakukan observasi tes keterampilan pukulan dropshot dengan dibantu pelatih melakukan pengamatan. Hasil observasi diperoleh keterangan bahwa: (1) pada sikap persiapan nilai 1 di peroleh persentase sebesar $13,3 \%$, pada sikap persiapan nilai 2 diperoleh persentase sebesar $21,6 \%$, pada sikap persiapan nilai 3 diperoleh persentase sebesar $10 \%$, (2) pada sikap memukul nilai 1 diperoleh persentase $10 \%$, pada sikap memukul nilai 2 diperoleh persentase 15\%, pada sikap memukul nilai 3 diperoleh persentase $11,6 \%$, (3) pada sikap lanjutan nilai 1 diperoleh persentase 20\%, pada sikap lanjutan nilai 2 diperoleh persentase $10 \%$, pada sikap lanjutan nilai 3 diperoleh persentase $15 \%$.

Berdasarkan hasil wawancara kepada pelatih PB. Sari Agung Kabupaten Banyuwangi diperoleh hasil: (1) latihan dalam satu minggu sebanyak 6 kali (Senin, Selasa, Rabu, Kamis, Jumat, Sabtu) dan hanya hari Minggu libur, (2) latihan dimulai pukul 14.00-19.00 WIB serta setiap pertemuan 5-6 jam kecuali fisik 1 jam, (3) untuk pembelajaran teknik, pegangan, servis, pukulan, (4) untuk yang punya bakat di bidang cabang olahraga bulutangkis lebih cepat, (5) pukulan yang menonjol dari pantauan saya yaitu pukulan forehand dan netting, (6) rata-rata itu yang kurang bagus di smash, dropshot, backhand, (7) pernah, (8) menurut pelatih belum menguasai teknik dropshot, (9) pernah, dilihat waktu latihan dan kejuaraan sangat kurang menguasai dropshot, (10) iya, agar atlet itu bisa baik melakukannya, (11) latihan drill dan lemparan bola, (12) bisa, nanti dilakukan pada sela-sela latihan smash, (13) variasi, tapi fokusnya akurasi dan ketepatan bola.

Dari pendapat tersebut dapat disimpulkan bahwa kurangnya model latihan yang diberikan oleh pelatih selama itu sehingga penghambat untuk dapat meningkatkan pukulan forehand dropshot, untuk itu peneliti bermaksud melakukan penelitian meningkatkan pukulan dropshot menggunakan metode variasi latihan atlet. Dari penelitian yang akan dilakukan, peneliti mengkaji penelitian sejenis yang terkait dengan forehand dropshot yang ditulis oleh Mahmuda Permata Sari tahun 2016 yang berjudul "Upaya Meningkatkan Pukulan Forehand Dropshot Bulutangkis Menggunakan Metode Drill Bagi Atlet Usia 8-12 Tahun Di PB. Brawijaya Jr. Kota Malang".

Berdasarkan latar belakang masalah yang telah dipaparkan di atas, maka peneliti akan melakukan penelitian tindakan olahraga dengan judul "Upaya Meningkatkan Pukulan Forehand Dropshot Bulutangkis Menggunakan Metode Variasi Latihan Bagi Atlet Usia 8-12 Tahun Di PB. Sari Agung Genteng Kabupaten Banyuwangi". Tujuan dari penelitian ini adalah untuk dapat meningkatkan pukulan forehand dropshot menggunakan metode variasi latihan bagi atlet usia 8-12 tahun PB. Sari Agung Genteng Kabupaten Banyuwangi. 


\section{METODE}

Penelitian ini menggunakan jenis penelitian tindakan olahraga (PTO) yaitu penelitian yang diadaptasi dari penelitian tindakan kelas (PTK). Tujuan dari penelitian ini adalah memperbaiki serta meningkatkan keterampilan pukulan forehand dropshot kepada atlet PB. Sari Agung Genteng Kabupaten Banyuwangi menggunakan metode variasi latihan. Maka dilaksanakan penelitian ini sebagai tindak lanjut dari observasi analisis kebutuhan atlet yang menyatakan bahwa perlu adanya peningkatan keterampilan pukulan forehand dropshot.

Pada penelitian ini peneliti bertindak sebagai perancang tindakan, pengumpul data, penganalisa data, dan serta pelapor dari hasil. Jadi, kehadiran peneliti sangat dibutuhkan pada setiap aktivitas di tempat penelitian agar tujuan penelitian tercapai. Penelitian ini melibatkan 2 jajaran pelatih sebagai observer agar data yang diperoleh lebih akurat yang diamati.

Penelitian tindakan olahraga (PTO) ini dilakukan pada atlet PB. Sari Agung Genteng Kabupaten Banyuwangi pada usia 8-12 tahun sebanyak 20 atlet. PB. Sari Agung beralamatkan di Jl. Curah Ketangi Barat, Desa Setail, Kecamatan Genteng, Kabupaten Banyuwangi. Program latihan di PB. Sari Agung Kabupaten Banyuwangi dalam satu minggu sebanyak 6 pertemuan yaitu hari Senin, Selasa, Rabu, Kamis, Jumat, Sabtu latihan dimulai pukul 14.00-19.00 WIB.

Subjek dari hasil penelitian ini adalah 20 atlet bulutangkis PB. Sari Agung Genteng Kabupaten Banyuwangi yang terdiri dari 16 atlet laki-laki dan 4 atlet perempuan.

Data yang diperoleh dari penelitian ini yaitu melalui wawancara, hasil observasi dan tes keterampilan permainan bulutangkis. Sumber data yang didapat dari penelitian ini berasal dari PB. Sari Agung Genteng Kabupaten Banyuwangi.

Untuk mendapatkan pengumpulan data perlu adanya instrumen yang digunakan, dalam penelitian ini menggunakan metode pengambilan data berdasarkan pendapat dari Suprapto, Supriyadi, \& Merawati (2019) yang menyatakan bahwa teknik pengumpulan data dapat dilakukan dengan observasi (pengamatan), interview (wawancara), kuisioner (angket), dokumentasi, dan gabungan keempatnya. Dari hasil pengamatan peneliti dengan beberapa komponen yaitu: permainan, keterampilan, wawancara, penyebaran angket kemudian hasil tersebut dituangkan ke dalam pengamatan(Fathoni, 2018).

Penelitian ini menggunakan 2 teknik analisis data yaitu teknik analisis kualitatif dan kuantitatif. Pada pernyataan dijelaskan dapat disimpulkan bahwa pada tahap reduksi data memerlukan kecerdasan yang tinggi proses berfikir. Penyajian data pada penelitian kualitatif berupa uraian singkat, bagan, hubungan antar kategori. Sedangkan untuk verifikasi data masih bersifat sementara dan masih bisa diubah jika ditemukan bukti yang kuat.

$$
\mathrm{P}=\frac{f}{N} \mathrm{X} 100 \%
$$

$P=$ Angka persentase

$f=$ Jumlah nilai

$N=$ Jumlah frekuensi

Taraf keberhasilan tindakan ditentukan dengan berpedoman pada persentase keberhasilan tindakan yang telah dihitung.

Tabel 2. Penentuan Taraf Keberhasilan Tindakan (Fikri, 2017)

\begin{tabular}{cc}
\hline $\begin{array}{c}\text { Taraf keberhasilan } \\
\text { Tindakan }\end{array}$ & Keterangan \\
\hline $81-100 \%$ & Sangat baik \\
$61-80 \%$ & Baik \\
$41-60 \%$ & Cukup \\
$21-40 \%$ & Kurang \\
$0-20 \%$ & Sangat Kurang \\
\hline
\end{tabular}


Evaluasi pada penelitian yang digunakan penelitian ini yaitu metode variasi latihan untuk mengetahui apakah terdapat peningkatan keterampilan pukulan forehand dropshot yang dilakukan di PB. Sari Agung Genteng Kabupaten Banyuwangi.

Refleksi pada Penelitian Tindakan Olahraga (PTO) meliputi kegiatan menganalisis, memaknai atau mengartikan, menjelaskan serta menyimpulkan data yang telah didapat dari hasil saat observasi serta mengaitkan dengan teori yang digunakan. Selanjutnya hasil refleksi digunakan sebagai dasar untuk menentukan siklus pada tahap selanjutnya.

Penelitian akan dilaksanakan bedasarkan prosedur penelitian tindakan kelas dengan siklus sebagai berikut:

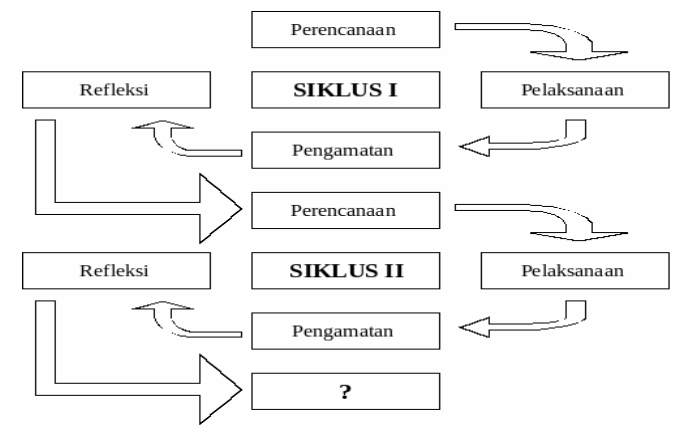

Gambar 1. Siklus Penelitian Tindakan (Sugiarto, Tomi, \& Fauzi, 2020)

Berikut ini adalah penjelasan dari ilustrasi tersebut:

\section{Siklus 1}

Tahap pada siklus 1 meliputi: perencanaan tindakan 1 , pelaksanaan tindakan 1 , observasi 1 , dan refleksasi 1. Tiap-tiap siklus terdiri dari 4 pertemuan.

\section{Perencanaan Siklus 1}

Pada perencanaan tindakan 1 ini ada beberapa kegiatan yang dilakukan oleh peneliti, antara lain: (1) membuat skenario atau rancangan program latihan pukulan forehand dropshot di klub PB. Sari Agung Kabupaten Banyuwangi, (2) mempersiapkan sarana dan prasarana untuk menunjang proses kegiatan latihan, (3) mempersiapkan instrumen tentang latihan pukulan forehand dropshot dengan menggunakan variasi latihan.

\section{Pelaksanaan Tindakan I}

Pada pelaksanaan tindakan I dilakukan sesuai rencana dengan perencanaan tindakan I, kegiatan yang dilakukan pada tahap ini adalah atlet melaksanakan program latihan pukulan forehand dropshot dengan metode latihan bervariasi sesuai program yang dirancang peneliti.

\section{Observasi Tindakan I}

Catatan lapangan yang harus diperoleh oleh peneliti pada saat pengamatan anatara lain: (1) peneliti mencatat situasi dalam proses latihan, (2) mencatat variasi latihan pukulan forehand dropshot sesuai kriteria yang telah dilakukan, (3) mengamati sikap dan kedisiplinan atlet saat proses latihan dilakukan, (4) mengamati dan mencatat keaktifan atau keseriusan pelaksanaan latihan dilakukan.

\section{Refleksi I}

Refleksi merupakan kegiatan penilaian ataupun menelaah secara mendalam dan menyeluruh terhadap apa saja yang telah terjadi. Refleksi pada akhir siklus dilakukan oleh peneliti, pelatih sekaligus sebagai observer dan observer lain yang memiliki lisensi. Tujuan dari refleksi ini untuk menganalisis proses latihan pukulan forehand dropshot dan untuk bahan acuan untuk mencari kesalahan atau kurangnya efektifitas dalam proses latihan forehand dropshot di PB. Sari Agung Kabupaten Banyuwangi. Langkah-langkah yang dilakukan pada saat refleksi antara lain sebagai berikut: (1) pengumpulan hasil data observasi dan catatan lapangan kemudian dianalisis, (2) refleksi pada kesimpulan akhir apakah indikator keberhasilan telah mencapai standart peneliti sebesar $75 \%$, jika belum maka dilanjutkan pada siklus berikutnya. 


\section{Siklus II}

Tahap pada siklus II diantaranya perencanaan II, pelaksanaan II, observasi II, refleksi II. Masing-masing terdiri dari 4 pertemuan.

\section{Perencanan Siklus II}

Pada perencanaan tindakan 2 ini ada beberapa kegiatan yang dilakukan oleh peneliti, antara lain: (1) melihat dari hasil pada siklus I, peneliti dan pelatih bekerjasama untuk memperbaiki program latihan yang masih memiliki kekurangan -kekurangan agar dapat meningkatkan hasil yang lebih baik dan maksimal pada siklus II, (2) mempersiapkan kembali instrumen kegiatan latihan pukulan forehand dropshot dengan menggunakan variasi latihan.

\section{Pelaksanaan Tindakan II}

Pelaksanaan tindakan II ini dilakukan sesuai rencana dengan perencanaan tindakan 1 yang telah diperbaiki, kegiatan yang dilakukan pada tahap ini adalah atlet melaksanakan program latihan pukulan forehand dropshot dengan metode latihan variasi sesuai dengan program yang telah dirancang oleh peneliti.

\section{Observasi Tindakan II}

Pada tahap observasi ini peneliti mengumpulkan data dengan mencatat atau menulis hasil pengamatan yang dilakukan atlet pada saat proses latihan di PB Sari Agung Kabupaten Banyuwangi. Instrumen yang digunakan dalam kegiatan ini adalah berupa catatan lapangan dari segala aktivitas selama proses latihan pukulan forehand dropshot. Pengamatan proses latihan pada siklus II ini nantinya akan dijadikan perbandingan untuk hasil pada siklus 1.

\section{Refleksi II}

Pada tahap refleksi II ini kegiatan yang dilakukan peneliti, pelatih, dan observer adalah menganalisis apakah terdapat peningkatan teknik dasar pukulan forehand dropshot terhadap atlet setelah digunakan program variasi latihan yang dibuat oleh peneliti. Setelah seluruh siklus dilakukan dan catatan lapangan diamati maka pelatih, peneliti dan observer berdiskusi apakah hasil seluruh siklus 1 dan 2 telah mencapai standart peneliti yaitu $75 \%$.

\section{HASIL}

Setelah peneliti mengetahui kesulitan yang dialami oleh atlet usia 8-12 tahun di klub PB. Sari Agung Kabupaten Banyuwangi, selanjutnya peneliti dan pelatih merancang program latihan untuk 4 kali pertemuan dan menyiapkan lembar observer dan catatan lapangan. Berikut program model latihan variasi pukulan forehand dropshoot bulutangkis: (1) model latihan variasi 1 yaitu pukulan forehand dropshoot arah bola silang 1, (2) model latihan variasi 2 yaitu pukulan forehand dropshoot arah bola silang 2, (3) model latihan variasi 3 yaitu pukulan forehand dropshoot arah bola lurus 1, (4) model latihan variasi 4 yaitu pukulan forehand dropshoot arah bola lurus 2.

Pelaksanaan tindakan 1 dilaksanakan pada tanggal 14, 15, 16, 17, 19 Oktober 2019 dimulai pukul 15.00-17.30 WIB di GOR Graha Bhakti Sport Centre. Dalam proses pelaksanaan tindakan 1, peneliti di bantu oleh pelatih dan juga observer atau pengamat yang sudah memiliki lisensi yaitu ahli tentang bulutangkis untuk mengamati jalannya proses latihan. Berikut program latihan yang di gunakan pada pertemuan pertama: (1) Variasi Latihan forehand dropshot model 1, (2) Latihan Shadow pukulan Forehand Dropshoot. Pertemuan kedua: (1) Variasi Latihan forehand dropshot model 2, (2) Latihan Shadow pukulan Forehand Dropshoot. Pertemuan ketiga: (1) Variasi Latihan forehand dropshot model 3, (2) Latihan Shadow pukulan Forehand Dropshoot. Pertemuan keempat: (1) Variasi Latihan forehand dropshot model 4, (2) Latihan Shadow pukulan Forehand Dropshoot. Pertemuan kelima: (1) Variasi Latihan forehand dropshot model 1 dan 2, (2) Latihan Shadow pukulan Forehand Dropshoot.

Dari hasil pengamatan yang dilakukan pada pelaksanaan tindakan 1 selama 5 kali pertemuan yang dilaksanakan pada tanggal 14, 15, 16, 17, 19 Oktober 2019 dimulai pukul 15.00-17.30 WIB di GOR Graha Bhakti Sport Centre dengan materi teknik pukulan forehand dropshot bulutangkis di klub PB. Sari Agung Kabupaten Banyuwangi diperoleh hasil pada Tabel 3 sebagai berikut. 
Tabel 3. Data Hasil Penilaian Siklus 1.

\begin{tabular}{|c|c|c|c|c|}
\hline & & $\begin{array}{l}\text { Gerakan Teknik } \\
\text { Bulutagkis }\end{array}$ & Pukulan Fo & Dropshot \\
\hline & & Sikap Persiapan & Sikap Memukul & Sikap Lanjutan \\
\hline (Observer 1) & & 57,41 & 51,85 & 51,85 \\
\hline (Observer 2) & & 57,41 & 53,70 & 53,71 \\
\hline $\begin{array}{l}\text { (Observasi } 1 \text { ) Presentase } \\
\text { Keseluruhan (\%) }\end{array}$ & Ketuntasan & 53,70 & & \\
\hline $\begin{array}{l}\text { (Observasi } \quad 2 \text { ) Presentase } \\
\text { Keseluruhan (\%) }\end{array}$ & Ketuntasan & 54,94 & & \\
\hline
\end{tabular}

Dari hasil pengamatan Tabel 3 persentase penilaian pada siklus 1 dapat diketahui bahwa pada sikap persiapan didapatkan persamaan antara observer, dimana baik observer 1 maupun observer 2 mendapatkan hasil sebesar 57,41\%. Kedua, pada indikator sikap memukul observer 1 mendapatkan hasil 51,85\%, sedangkan observer 2 mendapatkan hasil sebesar 53,70\%. Ketiga, pada indikator sikap lanjutan hasil yang didapatkan dari observer 1 sebesar $51,85 \%$ dan observer 2 mendapatkan hasil yang sama yaitu sebesar $53,71 \%$.

Setelah melaksanakan program latihan pada tindakan 1 selama 5 kali pertemuan, peneliti bekerjasama dengan pelatih melakukan refleksi kegiatan dari siklus 1. Adapun hasil refleksi dari kegiatan siklus 1 diantaranya: (1) persentase ketuntasan pada atlet klub PB. Sari Agung Genteng Kabupaten Banyuwangi usia 8-12 tahun hasil analisa dari observer 1 sebanyak 53,70\%, (2) persentase ketuntasan pada atlet PB. Sari Agung Genteng Kabupaten Banyuwangi usia 8-12 tahun hasil analisa dari observer 2 sebanyak 54,94\%, (3) rata-rata persentase ketuntasan pada atlet klub PB. Sari Agung Genteng Kabupaten Banyuwangi usia 8-12 tahun hasil analisa dari observer 1 dan 2 sebanyak 54,32\%, (4) perlu adanya tindakan berupa teguran kepada atlet yang kurang fokus dalam melaksanakan program latihan variasi forehand dropshot, (5) perlu adanya tindakan dari pelatih berupa teguran bagi atlet yang datang terlambat dan atlet yang kurang fokus karena bergurau dalam melaksanakan program latihan variasi forehand dropshot, (6) perlu adanya perubahan program latihan yang lebih bervariasi dan beragam karena sebagian atlet sudah mulai merasa jenuh dan bosan pada saat latihan berlangsung.

Berdasarkan dari hasil refleksi yang diadakan oleh peneliti bersama pelatih, peneliti bersama pelatih mencoba untuk memperbaiki baik dari segi program latihan dan cara penyampaian materi yang lebih variatif dan jelas lagi supaya dapat meningkatkan teknik pukulan forehand dropshot bulutangkis sehingga nantinya mendapatkan hasil yang optimal.

\section{Temuan Siklus 2}

Berdasarkan hasil evaluasi dan refleksi yang dilaksankan oleh peneliti bersama pelatih pada siklus 1 , selanjutnya dilakukan upaya untuk meningkatkan keterampilan teknik pukulan forehand dropshot bulutangkis menggunakan model latihan variasi. Peneliti bersama dengan pelatih menyiapkan kembali program latihan untuk 5 kali pertemuan pada siklus 2, lembar observer, dan catatan lapangan yang nantinya digunakan pada proses di siklus 2. Peneliti bersama dengan pelatih sepakat untuk menggunakan model latihan variasi yang sama dengan model latihan variasi yang digunakan pada siklus 1 berdasarkan hasil pada siklus 1 yang sudah meningkat hanya saja masih kurang maksimal sehingga peneliti bersama dengan pelatih hanya merubah susunan model latihan variasinya yang akan digunakan pada siklus 2. Berikut program latihan variasi pukulan forehand dropshot bulutangkis: (1) model latihan variasi 1 yaitu pukulan forehand dropshoot arah bola silang 1, (2) model latihan variasi 2 yaitu pukulan forehand dropshoot arah bola silang 2, (3) model latihan variasi 3 yaitu pukulan forehand dropshoot arah bola lurus 1, (4) model latihan variasi 4 yaitu pukulan forehand dropshoot arah bola lurus 2.

Pelaksanaan tindakan 2 dilaksanakan pada tanggal 26 Oktober 2019, tanggal 28 Oktober 2019, tanggal 29 Oktober 2019, tanggal 30 Oktober 2019, dan tanggal 2 November 2019 pada pukul 15.00-17.30 WIB di GOR Graha Bhakti Sport Centre, Curahketangi Setail Kabupaten Banyuwangi. Dalam proses pelaksanaan tindakan 2, peneliti dibantu oleh pelatih dan juga observer atau pengamat yang sudah memiliki lisensi yaitu ahli tentang bulutangkis untuk mengamati jalannya proses latihan. Berikut program latihan yang di gunakan pada pertemuan pertama: (1) Variasi Latihan forehand dropshot model 1 dan 2, (2) Latihan Shadow pukulan 
Forehand Dropshoot, (3) Latihan skipping. Pertemuan kedua: (1) Variasi Latihan forehand dropshot model 3 dan 4, (2) Latihan Shadow pukulan Forehand Dropshoot, (3) Latihan skipping. Pertemuan ketiga: (1) Variasi Latihan forehand dropshot model 1 dan 3, (2) Latihan Shadow pukulan Forehand Dropshoot, (3) Latihan skipping. Pertemuan keempat: (1) Variasi Latihan forehand dropshot model 2 dan 4, (2) Latihan Shadow pukulan Forehand Dropshoot, (3) Latihan skipping. Pertemuan kelima: (1) Variasi Latihan forehand dropshot model 1 dan 4, (2) Latihan Shadow pukulan Forehand Dropshoot, (3) Latihan skipping.

Dari hasil pengamatan yang dilakukan pada pelaksanaan tindakan 2 selama 5 kali pertemuan yang dilaksanakan pada tanggal 26 Oktober 2019, tanggal 28 Oktober 2019, tanggal 29 Oktober 2019, tanggal 30 Oktober 2019, dan tanggal 2 November 2019 pada pukul 15.00-17.30 WIB di GOR Graha Bhakti Sport Centre, Curahketangi Setail Kabupaten Banyuwangi dengan materi teknik pukulan forehand dropshot bulutangkis di klub PB. Sari Agung Genteng Kabupaten Banyuwangi diperoleh hasil pada Tabel 4 sebagai berikut.

Tabel 4. Data Hasil Penilaian Siklus 2.

\begin{tabular}{|c|c|c|c|c|}
\hline & & $\begin{array}{l}\text { Gerakan Teknik } \\
\text { Bulutagkis }\end{array}$ & Pukulan & Dropshot \\
\hline & & Sikap Persiapan & Sikap Memukul & Sikap Lanjutan \\
\hline (Observer 1) & & 88,33 & 80,00 & 78,33 \\
\hline (Observer 2) & & 88,33 & 83,33 & 81,67 \\
\hline $\begin{array}{l}\text { (Observasi 1) Presentase } \\
\text { Keseluruhan (\%) }\end{array}$ & Ketuntasan & 82,22 & & \\
\hline $\begin{array}{l}\text { (Observasi 2) Presentase } \\
\text { Keseluruhan (\%) }\end{array}$ & Ketuntasan & 84,44 & & \\
\hline
\end{tabular}

Dari hasil pengamatan Tabel 4 persentase penilaian pada siklus 2 dapat diketahui bahwa pada sikap persiapan hasil yang didapat dari observer 1 maupun observer 2 sebesar $88,33 \%$. Kedua, pada indikator sikap memukul hasil yang didapatkan oleh observer 1 sebesar $80 \%$ sedangkan hasil yang didapatkan oleh observer 2 sebesar $83,33 \%$. Ketiga, pada indikator sikap lanjutan hasil yang didapatkan dari observer 1 sebesar $78,33 \%$ sedangkan observer 2 mendapatkan hasil $81,67 \%$.

Setelah melaksanakan program latihan pada siklus 2 selama 5 kali pertemuan, peneliti bersama pelatih melakukan refleksi kegiatan di siklus 2. Adapun hasil refleksi dari siklus 2 sebagai berikut: (1) persentase ketuntasan pada atlet klub PB. Sari Agung Genteng Kabupaten Banyuwangi usia 8-12 tahun hasil analisa dari observer 1 sebanyak 82,22\%, (2) Persentase ketuntasan pada atlet klub PB. Sari Agung Genteng Kabupaten Banyuwangi usia 8-12 tahun hasil analisa dari observer 2 sebanyak 84,44\%, (3) rata-rata persentase ketuntasan pada atlet klub PB. Sari Agung Genteng Kabupaten Banyuwangi usia 8-12 tahun hasil analisa dari observer 1 dan 2 sebanyak 83,33\%, (4) atlet sudah melakukan pukulan forehand dropshot dengan baik menggunakan model variasi latihan tetapi perlu ditingkatkan dengan diawasi oleh pelatih.

Hasil penelitian yang telah dilaksanakan pada tindakan 2 mengenai peningkatan keterampilan pukulan forehand dropshot bulutangkis atlet klub PB. Sari Agung Genteng Kabupaten Banyuwangi usia 8-12 tahun, dapat disimpulkan bahwa pada tindakan 2 mengalami peningkatan. Maka bisa dikatakan bahwa tujuan dari penelitian ini telah tercapai dan tidak perlu diadakan tindak lanjut pada siklus berikutnya.

Berdasarkan hasil perbandingan dari siklus 1 dan siklus 2 yang terdapat pada tabel 5.3, dapat disimpulkan bahwa: (1) terlihat dari siklus 1 dan siklus 2 persentase ketuntasan para atlet yang dilakukan oleh observer 1 maupun observer 2 mengalami peningkatan yang signifikan, walaupun hasil persentase ketuntasan dari observer 2 lebih tinggi dibanding dengan observer 1, (2) peningkatan persentase ketuntasan dilihat dari pertemuan pertama dimana penilaian dari observer 1 sebesar $38,89 \%$ dan observer 2 sebesar $38,89 \%$ hingga pertemuan terakhir dari observer 1 sebesar 82,22\% dan observer 2 sebesar 84,44\%, (3) peningkatan persentase ketuntasan dari siklus 1 dan siklus 2 dikarenakan ketika melakukan program latihan dengan metode latihan variasi para atlet sudah melakukan dengan baik. 


\section{PEMBAHASAN}

Dari hasil yang dipaparkan tersebut, dapat dilihat pada Tabel 2 mengenai kriteria persentase ketuntasan yang mana dijelaskan bahwa jika melebihi $70 \%$ masuk dalam kategori cukup dan dapat digunakan. Sementara hasil yang telah didapat peneliti mendapatkan hasil dari observer 1 sebanyak 82,22\% dan observer 2 sebanyak $84,44 \%$ masuk dalam kategori baik hingga sangat baik. Sehingga dapat disimpulkan bahwa dengan menggunakan metode latihan variasi dapat meningkatkan teknik pukulan forehand dropshot bagi atlet usia 812 tahun di klub PB. Sari Agung Genteng Kabupaten Banyuwangi.

Peneliti mengkaji dari penelitian sebelumnya dengan penggunaan metode latihan variasi dapat meningkatkan teknik pukulan forehand dropshot bulutangkis, dijelaskan oleh Mahmuda Permata Sari (2018) bahwa "dengan menggunakan metode latihan variasi dapat meningkatkan teknik pukulan forehand dropshot bulutangkis pada atlet usia 8-12 tahun di PB. Brawijaya JR".

Penelitian lain oleh Pradana (2016) menjelaskan bahwa dengan menggunakan latihan drilling dan strokes pada pukulan dropshot dapat meningkatkan pukulan dropshot pada atlet usia 10-11 tahun PB Natura Prambanan Yogyakarta.

Penelitian oleh Susanto (2017) menjelaskan bahwa pengembangan model latihan pukulan forehand dropshot dapat meningkatkan keterampilan pukulan forehand dropshot pada siswa ekstrakurikuler di SMP Negeri 2 Trawas dengan hasil ujicoba sebesar $78,7 \%$ dan $80 \%$ dengan kriteria baik.

Penelitian oleh Kusuma (2017) menjelaskan bahwa latihan dropshot dengan menggunakan model latihan rintangan tali 0,5 meter dapat meningkatkan keterampilan pada permainan bulutangkis pada klub PB Bersama Masbagik Lombok Timur.

Penelitian oleh Pardiman, Sugiharto, \& RC (2018) menjelaskan bahwa latihan exercise dan koordinasi mata dan tangan dapat meningkatkan signifikan akurasi pukulan dropsot di PB C-PLUSco Semarang.

Penelitian juga dilakukan oleh El-Gezawi (2015) yang menjelaskan beberapa teknik dapat dilatih menggunakan model-model atau variasi-variasi latihan tertentu salah satunya adalah forehand dropshot. Dalam penelitiannya diterapkan maca-macam latihan yang mengarah ke kemampuan visual dalam pertandingan bulutangkis.

Penelitian yang telah dipaparkan diatas menjadi pendukung dari penelitian yang dilakukan oleh peneliti tentang pukulan forehand dropshot bulutangkis pada atlet usia 8-12 tahun di PB Sari Agung Kabuaten Banyuwangi dengan hasil dari observer 1 sebanyak $82,22 \%$ dan observer 2 sebanyak $84,44 \%$ masuk dalam kategori baik hingga sangat baik.

\section{KESIMPULAN}

Berdasarkan hasil Penelitian Tindakan Olahraga (PTO) yang telah dilaksanakan pada keterampilan pukulan forehand dropshot bagi atlet usia 8-12 tahun di PB. Sari Agung Genteng Kabupaten Banyuwangi, maka dapat disimpulkan bahwa dengan menggunakan 4 model variasi latihan pukulan forehand dropshoot, yaitu: (1) variasi latihan forehand dropshot arah bola silang 1, (2) variasi latihan forehand dropshot arah bola silang 2, (3) variasi latihan forehand dropshoot arah bola lurus 1, (4) variasi latihan forehand dropshot arah bola lurus 2 dapat meningkatkan keterampilan pukulan forehand dropshot bagi atlet usia 8-12 tahun di PB. Sari Agung Banyuwangi Genteng Kabupaten Banyuwangi.

Adapun saran yang bisa peneliti berikan yaitu: (1) dengan menggunakan model variasi latihan dapat meningkatkan keterampilan pukulan forehand dropshot bulutangkis bagi atlet di PB. Sari Agung Genteng Kabupaten Banyuwangi, (2) bagi pelatih diharapkan hasil penelitian dapat dijadikan acuan untuk dapat meningkatkan keterampilan pukulan forehand dropshot bulutangkis di PB. Sari Agung Genteng Kabupaten Banyuwangi, (3) atlet dapat meningkatkan pukulan forehand dropshot bulutangkis secara mandiri ataupun dengan bantuan pelatih. 


\section{Ucapan Terima Kasih}

Penulis menyampaikan terima kasih dan penghargaan setulus hati, kepada, (1) Dr. Sapto Adi, M. Kes., selaku Dekan Fakultas IImu Keolahragaan (FIK) Universitas Negeri Malang (UM) yang telah memberikan kesempatan untuk menempuh jenjang Sarjana di FIK UM. (2) Dr. dr. H. M. Yunus, M.Kes., selaku Wakil Dekan I FIK UM yang telah membantu dan memberikan ijin dalam proses penelitian ini. (3) Dr. Lokananta Teguh Hari Wiguno, M.Kes., selaku Ketua Jurusan Pendidikan Jasmani dan Kesehatan, Fakultas IImu Keolahragaan yang telah membimbing, memberi masukan, saran, dan arahan dalam penyelesaian skripsi ini. (4) Drs. Oni Bagus Januarto, M.Kes, selaku dosen pembimbing I dan Drs. Agus Tomi, M.Pd, selaku dosen pembimbing II, yang telah memberikan bimbingan, motivasi, arahan, saran dan masukan yang bermanfaat sehingga skripsi ini dapat terselesaikan. (5) Bapak dan Ibu Dosen Jurusan Pendidikan Jasmani dan Kesehatan telah memberikan ilmu yang bermanfaat selama peneliti menempuh perkuliahan. (6) Kedua orang tua Bapak H. Makinudin dan Ibu Hj. Mu'awanah, Saudara Muhamad Zuban Khonabis serta seluruh keluarga besar penulis yang telah memberikan motivasi dan dengan setulus hati memberikan kasih sayang sehingga skripsi ini dapat terselesaikan.

\section{DAFTAR PUSTAKA}

Adi, S., \& Fathoni, A. F. (2019). Development of Learning Model Based on Blended Learning in Sports School. https://doi.org/10.2991/acpes-19.2019.2

Adi, S., \& Fathoni, A. F. (2020). The effectiveness and efficiency of blended learning at sport schools in Indonesia. International Journal of Innovation, Creativity and Change.

Cohen, C., Texier, B. D., Quéré, D., \& Clanet, C. (2015). The physics of badminton. New Journal of Physics. https://doi.org/10.1088/1367-2630/17/6/063001

El-Gezawi, H. H. (2015). Effect of Visual Training on Accuracy of Attack Shots Performance in Badminton. Journal of Applied Sports Science, 5(4), 36-45. https://doi.org/10.21608/jass.2015.84524

Fathoni, A. F. (2018). The Role of Blended Learning on Cognitive Step in Education of Sport Teaching by Adjusting the Learning Style of the Students. https://doi.org/10.2991/isphe-18.2018.49

Fattahudin, M. A., Januarto, O. B., \& Fitriady, G. (2020). Upaya Meningkatkan Keterampilan Pukulan Forehand Smash Bulutangkis Dengan Menggunakan Model Variasi Latihan Untuk Atlet Usia 12-16 Tahun. Sport Science Health, 2(3), 182-194. Retrieved from http://journal2.um.ac.id/index.php/jfik/article/view/11493/5421

Fikri, A. (2017). Meningkatkan Kebugaran Jasmani Melalui Metode Latihan Sirkuit Dalam Pembelajaran Pendidikan Jasmani Olahraga Dan Kesehatan Di Sma Negeri 1 Lubuklinggau. Jurnal Pembelajaran Olahraga.

Kusuma, L. S. W. (2017). Pengaruh Latihan Dropshot Menggunakan Rintangan Tali 0,5 Meter terhadap Kemampuan Pukulan Forehand Overhead Drop Dalam Permainan Bulutangkis Pada Club PB. Bersama Masbagik Tahun 2015. Jurnal Pendidikan Olahraga Dan Kesehatan "GELORA," 4(1), 20-23. Retrieved from http://ojs.ikipmataram.ac.id/index.php/gelora/article/view/560/526

Paramitha, S. T., \& Anggara, L. E. (2018). Revitalisasi Pendidikan Jasmani untuk Anak Usia Dini melalui Penerapan Model Bermain Edukatif Berbasis Alam. JURNAL PENDIDIKAN JASMANI DAN OLAHRAGA. https://doi.org/10.17509/jpjo.ß3i1.10612

Pardiman, Sugiharto, \& RC, A. R. (2018). The Effects of Exercise \& Coordination Eyes-Hand against Drop Shot Accuracy in Badminton Athletes. Journal of Physical Education and Sports, 7(1), 68-72. Retrieved from https://journal.unnes.ac.id/sju/index.php/jpes/article/view/23328/10899

Phomsoupha, M., \& Laffaye, G. (2015). The Science of Badminton: Game Characteristics, Anthropometry, Physiology, Visual Fitness and Biomechanics. Sports Medicine. https://doi.org/10.1007/s40279-0140287-2

Pradana, A. F. (2016). Pengaruh Latihan Drilling Dropshot dan Strokes Dropshot terhadap Peningkatan Dropshot pada Atlet Bulutangkis Putra Usia 10-11 Tahun PB. Natura Prambanan Yogyakarta 
(Universitas Negeri Yogyakarta). https://doi.org/10.5151/cidi2017-060

Sugiarto, T. (Universitas N. M., Tomi, A. (Universitas N. M., \& Fauzi, I. A. (Universitas N. M. (2020). Upaya Meningkatkan Keterampilan Teknik Dasar Passing Futsal Menggunakan Metode Drill. Sport Science and Health, 2(3), 210-214. Retrieved from http://journal2.um.ac.id/index.php/jik/article/view/11801/5424

Suprapto, J., Supriyadi, \& Merawati, D. (2019). Pengaruh Latihan Beban Leg Press dan Squat Terhadap Power Otot Tungkai Pelari Di PASI Kota Malang. Sport Science, 1(3), 214-221. Retrieved from http://journal2.um.ac.id/index.php/jik/article/view/11358/4923

Susanto, R. (2017). Pengembangan Model Latihan Forehand Dropshot Bulutangkis Pada Siswa Ekstrakurikuler Smpn 2 Trawas Mojokerto. Jurnal Kejaora (Kesehatan Jasmani Dan Olahraga), 2(2), 102-121. https://doi.org/10.36526/kejaora. v2i2.127 